\title{
MENINGKATKAN TRANSPARANSI DAN DISIPLIN PASAR PERBANKAN SYARIAH DI INDONESIA
}

\author{
Hasan, Unwahas Semarang
}

\begin{abstract}
Supervision and market discipline is an act of market participants in response to the performance and risk of the bank. Market discipline has realized its importance in supporting the creation of a sound banking, and has been adopted in the Basel II as one of the pillars of sound banking. One of the prerequisites of effective market discipline is the transparency of bank information to market participants. Transparency and market discipline in Islamic banks are becoming more important as application -sharing system, in which the Islamic bank depositors are theoretically exposed to a bigher risk than conventional bank customers who receive definitive results. The importance of transparency and market discipline in Islamic banks has been realized with the formulation of the principles of transparency and disclosure of information in order to improve market discipline on banks by the sharia Islamic Financial Services Board (IFSB) in 2007.

This paper examines the theoretical framework of market discipline, the principles of transparency in promoting Islamic banking market discipline prepared by the IFSB, and various disciplines of research results in the banking market and the Indonesian Islamic banking. From the results of this study, formulated a variety of challenges and things that need to be considered to improve transparency and encourage market discipline of Islamic banking in Indonesia. At the end, delivered various subsequent recommendations to improve transparency and market discipline practices of Islamic banking in Indonesia .
\end{abstract}

Kata kunci : transparansi, disiplin pasar, bank syariah

\section{Pendahuluan}

Prinsip transparansi menjadi salah satu aspek penting dalam penyelenggaraan tata-kelola perusahaan yang baik (Good Corporate Governance GCG). Transparansi diperlukan agar para pemangku kepentingan (stakeholders) 
Meningkatkan Transparansi dan Disiplin Pasar Perbankan Syariahdapat mengambil keputusan dan tindakan yang tepat terhadap perusahaan tersebut. Transparansi ini sangat penting dan diperhatikan oleh para investor. Ketika investor memiliki akses informasi dan mengetahui kondisi perusahaan, investor lebih tertarik untuk berinvestasi pada perusahaan tersebut daripada perusahaan lain yang tidak memberikan akses informasi.

Pelaksanaan GCG pada industri perbankan syariah di Indonesia berlandaskan pada lima prinsip dasar sebagaimana diatur dalam Peraturan Bank Indonesia Nomor 11/ 33 /PBI/2009 tentang Pelaksanaan Good Corporate Governance bagi Bank Umum Syariah dan Unit Usaha Syariah. Pertama, transparansi (transparency), yaitu keterbukaan dalam mengemukakan informasi yang material dan relevan serta keterbukaan dalam proses pengambilan keputusan. Kedua, akuntabilitas (accountability) yaitu kejelasan fungsi dan pelaksanaan pertanggungjawaban organ bank sehingga pengelolaannya berjalan secara efektif. Ketiga, pertanggungjawaban (responsibility) yaitu kesesuaian pengelolaan bank dengan peraturan perundang-undangan yang berlaku dan prinsip-prinsip pengelolaan bank yang sehat. Keempat, profesional (professional) yaitu memiliki kompetensi, mampu bertindak obyektif dan bebas dari pengaruh/tekanan dari pihak manapun (independen) serta memiliki komitmen yang tinggi untuk mengembangkan bank syariah. Kelima, kewajaran (fairness) yaitu keadilan dan kesetaraan dalam memenuhi hak-hak stakeholders berdasarkan perjanjian dan peraturan perundang-undangan yang berlaku. Pelaksanaan GCG pada perbankan syariah dilakukan dalam rangka melindungi kepentingan stakeholders dan meningkatkan kepatuhan terhadap peraturan perundang-undangan yang berlaku serta nilai-nilai etika yang berlaku secara umum pada industri perbankan syariah.

Transparansi sangat diperlukan dalam dunia perbankan, mengingat pihak (nasabah) penyimpan dan investor berkepentingan terhadap keamanan dan pengelolaan dananya. Mekanisme pengawasan oleh para pelaku pasar terhadap risiko dan kinerja bank inilah yang disebut dengan disiplin pasar. Basel Committee on Banking Supervision (2001) telah menetapkan disiplin pasar menjadi salah satu pilar dari tiga elemen / pilar yang saling melengkapi dalam meningkatkan keamanan dan kesehatan (safety and soundness) perbankan dan sistem keuangan. Dua pilar yang lain adalah standar modal minimum dan proses pengawasan oleh regulator. Disiplin pasar memberikan insentif-insentif 
pada bank untuk melaksanakan bisnisnya dengan perilaku yang aman, baik, dan efisien, sehingga dapat meminimumkan kebutuhan modal minimum untuk mengantisipasi kerugian dan meminimumkan pengawasan dari regulator. Penerapan disiplin pasar membutuhkan pengungkapan informasi (disclosure) dan laporan keuangan oleh bank. Dengan pengungkapan ini, pasar dapat turut mengawasi kinerja dan risiko bank, sehingga mendorong bank untuk efisien dan mengendalikan risikonya.

Kesadaran akan mekanisme disiplin pasar pada bank syariah telah disadari secara International. Islamic Financial Services Board (IFSB) telah menyusun prinsip-prinsip pengungkapan untuk meningkatkan transparansi dan disiplin pasar bagi lembaga keuangan syariah, khususnya bank syariah. Prinsip-prinsip yang telah diterbitkan pada akhir 2007 ini menggambarkan kesadaran akan pentingnya disiplin pasar pada perbankan syariah pula.

Secara teoritis, kebutuhan akan transparansi dan mekanisme pendisiplinan pada bank syariah lebih penting karena pada bank syariah nasabah penyimpan (dengan akad mudharabah) dihadapkan pada risiko hasil yang lebih tinggi. Dengan akad bagi hasil, secara teoritis hasilnya dihadapkan pada ketidakpastian, sehingga risikonya lebih tinggi dibandingkan bank konvensional yang hasilnya pasti karena menggunakan sistem bunga. Hal ini diperkuat dengan hasil penelitian empiris persepsional oleh Ariffin et al (2005), yang menyatakan bahwa pengungkapan risiko dan transparansi pada bank syariah lebih ditekankan daripada bank konvensional terkait dengan sistem bagi hasil. Namun di lain sisi, hasil penelitiannya juga menunjukkan bahwa bank syariah masih kurang melakukan transparansi dan pengungkapan risikonya kepada publik, atau dengan kata lain transparansi yang dilakukan belum optimal. Hasi penelitian ini memperlihatkan pentingnya peningkatan transparansi dan disiplin pasar pada bank syariah.

\section{Kajian Teoritis Disiplin Pasar}

Lane (1993) mengartikan disiplin pasar dengan "pasar keuangan menyediakan sinyal-sinyal yang mengarahkan peminjam berperilaku secara konsisten dengan kondisi solvabilitasnya". Sinyal disiplin pasar ini dapat 


\section{Meningkatkan Transparansi dan Disiplin Pasar Perbankan Syariah}

dilakukan oleh nasabah penyimpan (depositors), pemegang-hutang (debt-holders), dan pemegang ekuitas (equity-bolders). Stephanou (2010) mendefinisikan disiplin pasar sebagai suatu mekanisme dimana para partisipan pasar memonitor dan mendisiplinkan perilaku pengambilan risiko yang berlebihan oleh bank. Berger (1991) dalam Levy-Yeyati et al (2004) menjelaskan disiplin pasar (market discipline) dalam dunia perbankan sebagai situasi dimana partisipan sektor swasta (pemegang obligasi, pemegang saham, lembaga pemeringkat, dan nasabah penyimpan) menghadapi biaya-biaya yang terkait positif dengan risiko bank dan bereaksi atas dasar biaya-biaya risiko ini.

Disiplin pasar bisa dipahami dalam bingkai konteks masalah umum principal-agent. Nasabah penyimpan (sebagai principal) ingin memastikan bahwa bank (sebagai agent) menjaga asetnya, yaitu simpanannya. Nasabah penyimpan mengawasi dan merespon peningkatan risiko bank. Respon atas peningkatan risiko ini dilakukan melalui pendekatan harga (dengan meningkatkan bunga simpanan), dan atau pendekatan kuantitas (dengan menarik dananya) (LevyYeyati et al, 2004). Disiplin pasar juga dapat dipahami dari signalling theory (teori pensinyalan) yang memperlihatkan bahwa ketika bank (sebagai perusahaan) berkinerja baik, bank akan memberi pertanda (sinyal) dengan memberikan kualitas informasi yang menunjukkan tingginya kinerja mereka kepada pasar. Pengungkapan informasi yang disampaikan pada pasar diharapkan akan mendorong pasar untuk mendisiplinkan manajemen (Ariffin et al, 2005).

Hamalainen et al (2003) menyusun kerangka teoritis yang menjelaskan disiplin pasar efektif sebagaimana terlihat pada gambar 1. Disiplin pasar terbagi menjadi dua tahapan besar : tahap pengenalan dan tahap pengendalian. Tahap pengenalan terdiri atas tiga sub-tahap : yaitu kesadaran investor bahwa dirinya menghadapi risiko kegagalan bank (default) dan dapat mengamati risiko kegagalan tersebut dengan efektif. Kesadaran ini akan mendorong investor/ pelaku pasar untuk memberikan sinyal kepada para peminjam dananya (dalam hal ini bank). Hal ini membutuhkan beberapa kondisi, yaitu : pasar modal harus terbuka, harus ada pengungkapan publik tentang susunan modal bank dan risiko yang dihadapi, dan partisipan pasar yang tepat. Partisipan pasar yang tepat tergantung dari karakteristik investor, karakteristik instrumen yang ada, dan tidak adanya kepercayaan bahwa peminjam (bank) akan di bail-out ketika 
terjadi kegagalan. Kepercayaan adanya bail-out akan menyebabkan adanya moral hazard' dan mengurangi disiplin pasar. Fenomena yang umum menyebabkan adanya moral hazard adalah "too-big-to-fail" dan penjaminan simpanan. Dua fenomena ini akan mendorong pengurangan disiplin pasar karena baik investor maupun peminjam merasa aman terhadap simpanannya dan keberadaaan bank tersebut yang dijamin oleh pemerintah.

Tahap pengendalian menekankan pentingnya struktur corporate governance yang baik untuk disiplin pasar yang efektif. Lingkungan corporate governance yang kuat akan mendorong manajemen bank mengoperasikan banknya dengan baik melalui pengendalian dan struktur organisasi yang akuntabel sehingga membatasi potensi perilaku pengambilan risiko yang berlebihan (excessive risktaking behaviour) atau tindakan yang tidak sesuai dengan tujuan investor. Dengan mekanisme pengendalian ini, bank (sebagai peminjam dana) akan berperilaku sesuai dengan risiko yang dihadapi, baik sebagai bentuk pendisiplinan secara langsung oleh para pemberi dana maupun sebagai pendisiplinan tidak langsung oleh otoritas pengatur perbankan.

Stephanou (2010) mengembangkan kerangka teoritis lain yang lebih sederhana untuk memahami dan menganalisa disiplin pasar, dengan membagi tahapan menjadi empat bagian yang saling terkait (gambar 2) : (1) informasi dan pengungkapan; diperlukan ketersediaan informasi publik yang mencukupi, konsisten, tepat waktu, dan handal mengenai kinerja keuangan dan eksposur risiko bank. (2) partisipan pasar; diperlukan keberadaan para partisipan pasar yang independen dan adanya insentif untuk mengawasi bank, serta kemampuan untuk memproses informasi yang diungkap dengan akurat. (3) mekanisme pendisiplinan; Perlu adanya berbagai instrumen, seperti instrumen keuangan, legal, atau pengawasan (disiplin pasar tidak langsung), yang dapat digunakan oleh para partisipan pasar untuk melakukan pendisiplinan. (4) tatakelola internal (internal governance); diperlukan adanya struktur organisasi dan kompensasi yang dapat menentukan apakah insiders (manajemen senior dan

1 Moral Hazard menurut Saunders dan Cornett (2008) adalah eksposur kerugian yang dihadapi oleh penjamin ketika pemberian jaminan mendorong pihak yang dijamin mengambil risiko lebih tinggi.

2 Too-big-to-fail menurut Saunders dan Cornett (2008) adalah bank-bank yang dipandang oleh otoritas pengatur (regulator) terlalu besar untuk ditutup dan dilikuidasi karena menimbulkan risiko sistemik terhadap sistem perbankan dan keuangan. 


\section{Meningkatkan Transparansi dan Disiplin Pasar Perbankan Syariah}

dewan direksi) memahami dan mengendalikan risiko yang diambil bank, dan ada insentif untuk mengubah perilakunya dalam merespon sinyal pasar.

Pada dua kerangka konseptual disiplin pasar perbankan tersebut, terlihat jelas arti penting transparansi dalam mendorong disiplin pasar. Stephanou (2010) menempatkan pengungkapan informasi atau ruh transparansi ini menjadi aspek penting pertama. Begitu pula dengan Hamalainen et al (2003, 2005) yang menempatkan transparansi menjadi kondisi yang harus ada dalam disiplin pasar yang efektif. Tanpa adanya pengungkapan informasi dan transparansi kondisi bank, para partisipan pasar tidak akan mengenali risiko yang dihadapi, sehingga tidak dapat melakukan tindakan-tindakan yang tepat dalam melakukan pendisiplinan pada manajemen bank.

\section{Gambar 2}

Kerangka Disiplin Pasar oleh Stephanou (2010)

\begin{tabular}{|c|c|}
\hline $\begin{array}{l}\text { Bagian } 1 \text { : Informasi dan } \\
\text { Pengungkapan } \\
\text { - } \quad \text { Pelaporan keuangan dan } \\
\text { akuntansi } \\
\text { - } \\
\text { Auditor eksternal } \\
\text { Pengungkapan yang berhati- } \\
\text { hati (Prudential disclosure) } \\
\text { - } \quad \text { Agen-agen rating kredit } \\
\text { Analis riset dan media }\end{array}$ & $\begin{array}{ll}\text { Bagian } 4 \text { : Internal Governance } \\
\text { - } & \text { Tatakelola risiko (risk } \\
& \text { governance) } \\
\text { - } & \text { Perencanaan remunerasi } \\
& \text { eksekutif } \\
\text { - } & \text { Komposisi dewan direksi/ } \\
& \text { komisaris, independensi, } \\
\text { dan kualifikasi }\end{array}$ \\
\hline Pengawasan (Monitc & Pengaruh (Influence) \\
\hline $\begin{array}{ll}\text { Bagian } 2 \text { : Partisipan Pasar } \\
\text { - } & \text { counterparties } \\
\text { - } & \text { nasabah penyimpan } \\
& \text { (depositors) } \\
\text { - } & \text { pemegang saham } \\
\text { - } & \text { investor hutang (debt } \\
& \text { holders) } \\
\text { - } & \text { clearinghouse }\end{array}$ & $\begin{array}{ll}\text { Bagian 3 : Mekanisme Pendisiplinan } \\
\text { - } & \text { Penyesuaian kuantitas/harga pada } \\
& \text { instrumen-instrumen finansial (ekuitas, } \\
& \text { hutang, simpanan, dll) } \\
\text { - } & \text { Jaminan/marjin yang diminta } \\
\text { - } & \text { Pasar untuk pengendalian korporasi } \\
\text { - } & \text { Perubahan aturan (legal redress) } \\
\text { - } & \text { Tindakan-tindakan pengawas } \\
& \text { (termasuk resolusi bank / mekanisme } \\
& \text { keluar) }\end{array}$ \\
\hline
\end{tabular}

Sumber : diterjemahkan dari Stephanou 


\section{Prinsip-Prinsip Transparansi Untuk Meningkatkan Disiplin Pasar Pada Bank Syariah}

IFSB telah menerbitkan standar prinsip-prinsip pengungkapan informasi bagi lembaga keuangan syariah pada tahun 2007. Sasaran dari standar ini adalah (a) memampukan para partisipan pasar dalam mendukung dan melengkapi implementasi kecukupan modal, manajemen risiko, dan tinjauan pengawasan dan standar corporate governance melalui tindakan-tindakan mereka di pasar keuangan; (b) menfasilitasi akses terhadap infomasi yang relevan, handal, dan tepat waktu oleh para partisipan pasar secara umum dan pemegang rekening investasi (Investment Account Holders - IAH) secara khusus, sehingga meningkatkan kapasitas mereka dalam mengawasi bank.

Penyajian yang dilakukan lembaga keuangan syariah hendaknya dapat mendorong para partisipan pasar secara umum, dan pemegang rekening investasi secara khusus, untuk mengakses informasi-informasi kunci mengenai tipe lembaga keuangan syariah; struktur modal dan ringkasan kecukupan modal; perlakukan pada rekening investasi termasuk risiko dan return-nya; proses manajemen risiko; eksposur risiko dengan tipe risiko dan indikator pembagian risiko dengan pemegang rekening investasi; aspek-aspek kunci tatakelola (governance) umum dan tata-kelola syariah; cakupan pengungkapan yang sesuai dengan konsumen (consumer-friendly) terkait jenis risiko dan hasil, kesesuaian syariah dan produk-produk rekening investasi; dan peranan unit usaha syariah (Islamic windows). Informasi-informasi yang dibutuhkan oleh pasar, sesuai dengan standar ini, hendaknya tersedia untuk digunakan, terpublikasi, mudah diakses, dan dapat diperoleh baik sebagai bagian dari laporan keuangan periodik atau melalui pengungkapan lain yang berorientasi konsumen/investor seperti prospektus atau catatan informasi lain. Pengungkapan informasi ini dilakukan secara periodik, dengan mencakup informasi kualitatif yang dipublikasikan setidaknya tahunan; dan informasi kuantitatif seperti modal utama, keseluruhan modal, CAR, dan komponenkomponennya, yang setidaknya dipublikasikan setiap triwulan. Informasi yang sesuai dengan standar umum hendaknya diterbitkan semesteran. Sedangkan informasi yang penting (material) harus dipublikasikan sesegera mungkin. 
Meningkatkan Transparansi dan Disiplin Pasar Perbankan Syariah

Lembaga keuangan syariah perlu membuat pengungkapan informasi tentang berbagai kebijakan, prosedur, desain produk, tipe produk dan dasar pembagian keuntungan investasi. Pengungkapan ini termasuk menjelaskan perbedaan antara akun investasi terbatas (restricted investment account holders ${ }^{3}$ ) dan investasi tak-terbatas (unrestricted investment account holders) ${ }^{4}$. Dalam konteks hubungan nasabah dengan bank, pengungkapan ini berarti mengungkap semua hak dan kewajiban masih-masing pihak, baik antara pihak nasabah dan pihak bank.

Prinsip-prinsip ini juga menekankan bahwa lembaga keuangan syariah juga perlu menyampaikan pengungkapan tata-kelola (governance) secara umum maupun pengungkapan tata-kelola syariah (syariah governance). Ada empat wilayah yang ditekankan dalam standar tata-kelola yang disusun oleh IFSB, yaitu pendekatan tata-kelola umum, hak-hak pemegang rekening investasi, kesesuaian dengan prinsip-prinsip dan aturan-aturan syariah, dan transparansi pelaporan keuangan dengan memperhatikan pemegang investasi.

Prinsip-prinsip pengungkapan informasi untuk meningkatkan transparansi dan disiplin pasar ini tidak hanya ditujukan pada Bank Syariah saja, tapi juga lembaga keuangan secara umum, kecuali asuransi dan reksadana syariah. Prinsip-prinsip ini merupakan prinsip keempat yang disusun IFSB sebagai pedoman lembaga keuangan syariah, khususnya pada bank syariah.

\section{Penelitian Sebelumnya}

Pengujian disiplin pasar pada perbankan di Indonesia pernah dilakukan Hosono et.al (2005), Jatna (2007), Valensi (2005), Taswan (2011) dan Hasan (2011). Hosono et.al (2005) meneliti keefektifan disiplin pasar oleh deposan selama periode 1992-2002 di empat negara yang terkena krisis finansial di Asia, yaitu : Indonesia, Korea, Malaysia, dan Thailand. Hasil penelitiannya memperlihatkan bahwa dalam periode krisis finansial di Indonesia, disiplin

\footnotetext{
${ }^{3}$ Restricted IAH adalah mudharabah muqayyadah, dimana bank (sebagai mudharib) dibatasi dengan kesepakatan dengan sahibul maal (pemilik dana) untuk menginvestasikan pada investasi tertentu saja.

${ }^{4}$ Unrestricted IAH adalah mudharabah mutlaqah, dimana bank (sebagai mudharib) tidak dibatasi untuk menginvestasikan pada investasi tertentu saja; kebijakan investasi diserahkan kepada bank (mudharib).
} 
pasar awalnya melemah dan kemudian menguat, sedangkan pada tiga negara lain (Korea, Malaysia, dan Thailand) justru tidak ditemukan disiplin pasar oleh deposan.

Jatna (2007) meneliti disiplin pasar pada 5 kelompok bank umum (bank pemerintah, bank swasta nasional, bank pembangunan daerah, bank campuran, dan bank asing) dengan data bulanan selama periode 2002.1 sampai 2005.12. Dengan menggunakan pendekatan kuantitas (perubahan simpanan) dan pendekatan harga (tingkat bunga), penelitian ini menyimpulkan bahwa disiplin pasar yang ada masih belum berjalan secara efektif. Kondisi tersebut ditengarai sebagai akibat rendahnya pemahaman masyarakat dalam memaknai istilah yang digunakan pada laporan keuangan bank dan adanya keterbatasan akses informasi kinerja individual bank. Penelitian ini juga menyimpulkan bahwa masyarakat telah memanfaatkan ketersediaan informasi berupa besarnya total asset dan rasio kredit bermasalah (non performing loan-NPL) sebagai dasar untuk menilai kinerja suatu bank. Selain itu, indikator suku bunga penjaminan juga digunakan oleh para deposan sebagai salah satu bahan pertimbangannya dalam menyimpan dana di bank.

Valensi (2005) menguji keberadaan disiplin pasar oleh deposan dan sesama bank (peer-banks) di Indonesia pada periode Januari 1980 sampai Desember 1999. Penelitian ini mengklasifikasikan bank atas dasar ada tidaknya hubungan kepemilikan dengan Pusat Kekuasaan Komersial (Commercial Power Centres - CPC) ${ }^{5}$. Hasilnya menunjukkan bahwa disiplin pasar tidak benar-benar terjadi di Indonesia. Disiplin pasar oleh deposan cenderung terjadi hanya pada bank-bank non-CPC. Penelitian ini secara umum menyarankan bahwa untuk negara-negara berkembang sebagaimana Indonesia, mekanisme disiplin pasar cenderung kurang efektif. Oleh karena itu, ia menyarankan bahwa otoritas moneter pada negara-negara berkembang hendaknya lebih menekankan pada pilar pertama (kecukupan modal) dan pilar kedua (pengawasan bank), daripada pilar ketiga (disiplin pasar).

5 . Hubungan kepemilikan dengan Pusat Kekuasaan Komersial (CPC) terdiri dari 200 kelompok bisnis yang digolongkan paling terkemuka, kepemilikan pemerintah (BUMN), penanaman modal asing, dan keluarga Suharto. 
Meningkatkan Transparansi dan Disiplin Pasar Perbankan Syariah-

Taswan (2011) meneliti tentang disiplin pasar sebagai kontrol risiko perbankan dan moral hazard terkait posisi charter value pada periode penjaminan simpanan implisit dan eksplisit. Sampel yang digunakan adalah seluruh bank umum non-pemerintah domestik yang ada di Indonesia pada periode 20012008. Salah satu temuannya adalah adanya disiplin pasar di Indonesia, dimana deposan memberikan hukuman bagi bank yang mengambil risiko tinggi dengan menarik dananya. Disiplin pasar pada masa penjaminan simpanan implisit dan pada masa penjaminan simpanan eksplisit tidak berbeda nyata secara statistik yang berarti menunjukkan bahwa disiplin pasar pada kedua masa ini berlaku tanpa membedakan skema penjaminan simpanan, dan semata-mata dilakukan deposan karena bank mengambil risiko yang tinggi.

Hasan dan Tandelilin (2012) menguji keberadaan disiplin pasar oleh deposan pada masa penjaminan simpanan oleh Lembaga Penjamin Simpanan (LPS). Data yang digunakan adalah data laporan keuangan tahunan 120 bank konvensional dan syariah dari Direktori Perbankan Indonesia untuk periode pengamatan disiplin pasar tahun 2005-2009. Hasil pengujian mengindikasikan adanya disiplin pasar di Indonesia, dengan adanya reaksi negatif deposan pada Aktiva Produktif Bermasalah (APB), reaksi postif deposan pada Net Interest Marjin (NIM), dan reaksi positif deposan terhadap Loan to Deposit Ratio (LDR). Reaksi deposan ini diproksikan dengan pertumbuhan simpanan deposito, yaitu reaksi positif ditandai dengan peningkatan deposito dan reaksi negatif ditandai dengan penurunan deposito. Penelitian ini juga memperlihatkan disiplin pasar pada periode 2005-2007 (periode sebelum kebijakan peningkatan penjaminan simpanan) lebih kuat terdeteksi daripada periode 2008-2009 (periode setelah kebijakan peningkatan penjaminan simpanan menjadi Rp 2 milyar). Meskipun belum kuat, penelitian ini mengindikasikan bahwa disiplin pasar oleh deposan bank syariah lebih kuat daripada disiplin pasar deposan pada bank konvensional. Hal ini sebagaimana diharapkan, dimana reaksi deposan pada bank syariah seharusnya memang lebih kuat mengingat deposan pada bank syariah dihadapkan pada risiko ketidakpastian hasil yang lebih tinggi sebagai konsekuensi akad bagi hasil.

Penelitian disiplin pasar khusus pada bank syariah secara internasional pernah dilakukan oleh Ariffin et al (2005). Penelitiannya mencermati isu transparansi dan disiplin pasar pada bank syariah dengan menggunakan survei 
kuesioner kepada 28 bank syariah di 14 negara pada lembaga pengawas bank, lembaga pemeringkat, auditor eksternal, dan perwakilan IFSB dan AAOIFI. Hasilnya memperlihatkan bahwa bank syariah masih kurang dalam pengungkapan risiko yang dihadapi. Meskipun demikian, ditemukan bahwa transparansi pada bank syariah lebih ditekankan dibandingkan bank konvensional terkait dengan sistem bagi hasil pada bank syariah.

Dari hasil penelitian di atas memperlihatkan variasi hasil disiplin pasar di Indonesia. Dilihat dari perbedaan waktu pengamatan disiplin pasar, terlihat bahwa kecenderungan disiplin pasar cenderung meningkat dari waktu ke waktu. Penelitian Valensi (2005) yang merupakan penelitian awal di Indonesia memperlihatkan adanya disiplin pasar yang masih lemah dan hanya pada bankbank yang tidak dekat dengan pusat kekuasaan (non-CPC), mengingat bank yang dekat dengan pusat kekuasaan (CPC) posisinya cenderung aman dan dilindungi oleh pemerintah pada masa rezim orde baru. Sesuai kerangka teoritis Hamalainen et al (2003;2005), hal ini karena bank yang dekat dengan pusat kekuasaan akan cenderung di bail-out oleh pemerintah.

Titik balik penguatan disiplin pasar tampaknya dimulai saat krisis moneter 1998. Hal diindikasikan dengan penelitian Hosono et al (2005) yang cenderung memperlihatkan penguatan disiplin pasar justru di masa krisis. Kecenderungan adanya disiplin pasar di Indonesia terus terlihat pada penelitian-penelitian setelah itu, sebagaimana hasil penelitian Jatna (2007) yang memperlihatkan adanya disiplin pasar oleh deposan meskipun belum kuat. Taswan (2011) juga memperlihatkan adanya disiplin pasar dengan pendekatan kuantitas (diproksikan dengan tingkat pertumbuhan simpanan) dan bukan dengan pendekatan harga (diproksikan dengan tingkat bunga). Penelitian Taswan ini memperlihatkan bahwa disiplin pasar tidak berbeda karena adanya penjaminan simpanan yang eksplisit ataupun implisit. Berbeda dengan hasil penelitian Hasan (2011) yang juga memperlihatkan adanya disiplin pasar, namun ada indikasi perbedaan disiplin pasar karena perubahan kebijakan penjaminan simpanan. Perbedaan hasil ini dimungkinkan karena perbedaan periode pengamatan dan kebijakan penjaminan yang berbeda pula. 
Meningkatkan Transparansi dan Disiplin Pasar Perbankan Syariab-

\section{Tantangan Peningkatan Transparansi dan Disiplin Pasar Perbankan Syariah}

Hasil penelitian Arifin et al (2005) menekankan pentingnya transparansi yang lebih besar pada bank syariah dibandingkan dengan bank konvensional sebagai konsekuensi sistem bagi hasil yang diterapkan. Transparansi ini perlu dilakukan dalam rangka meningkatkan disiplin pasar oleh nasabah (deposan) yang secara teoritis dihadapkan pada risiko yang lebih tinggi daripada bank konvensional.

Pelaksanaan transparansi ini juga harus dibarengi dengan kemampuan pasar untuk melakukan pengawasan. Karena itu, nasabah dan pelaku pasar yang lain, seharusnya memiliki kemampuan menggunakan informasi yang diperoleh (yang tak mungkin didapat jika tidak ada transparansi informasi kinerja dan risiko bank) sehingga dapat melakukan pengawasan dan mengambil tindakan yang sesuai dengan risiko dan kinerja bank tersebut. Untuk ini, para pelaku pasar, khususnya deposan, perlu didorong untuk turut melakukan pengawasan terhadap bank syariah. Disiplin pasar dapat "meringankan" tugas pengawasan Bank Indonesia karena terbantu mendisiplinkan manajemen bank. Oleh karena itu, Bank Indonesia selain perlu meningkatkan komitmen transparansi, juga perlu memperkuat kemampuan para pelaku pasar, termasuk nasabah untuk menggunakan informasi kondisi bank dalam pengambilan keputusan investasi yang tepat. Hal ini dapat dilakukan dengan meningkatkan program edukasi nasabah dan pelaku pasar bank syariah. Edukasi pasar bank syariah menjadi penting mengingat bank syariah relatif baru dan sistemnya belum dipahami mendalam dibandingkan dengan bank konvensional.

Kemampuan pasar dalam melakukan pengawasan semakin relevan dan seharusnya dilakukan oleh para pelaku pasar yang dananya relatif besar. Pelaku pasar (seperti deposan) besar memiliki kemampuan lebih, sehingga diharapkan lebih mampu melakukan pengawasan terhadap kinerja dan risiko bank. Nasabah dan investor besar lebih memiliki sumber daya dan akses informasi dalam melakukan pengawasan. Berbeda dengan pelaku pasar dan nasabah kecil yang tidak atau relatif kurang memiliki sumber daya dan kemampuan dalam melakukan pendisiplinan kepada manajer bank. Oleh karena itu, dapat 
dipahami perlindungan nasabah kecil melalui penjaminan simpanan. Saat ini simpanan yang dijamin hanya pada rekening simpanan nasabah di bawah Rp. 2 milyar. Hal ini untuk menghindari moral hazard, dimana nasabah besar yang seharusnya mampu melakukan pengawasan dan pendisiplinan pada bank tidak melakukannya karena telah dijamin.

Perbedaan operasional dan sistem bank syariah dibanding bank konvensional membawa konsekuensi perbedaan informasi yang disampaikan. Namun tantangannya adalah, bagaimana informasi kinerja dan risiko bank yang disampaikan ini tetap dapat diperbandingkan antara kinerja dan risiko bank syariah dengan bank konvensional. Pengungkapan informasi yang disampaikan hendaknya dapat diperbandingkan lebih lanjut, tidak hanya antar bank syariah namun juga bank syariah dengan bank konvensional. Informasi yang disampaikan bank syariah idealnya mencakup informasi yang ada pada bank secara umum ditambah dengan informasi tambahan yang relevan dan khusus pada bank syariah seperti kepatuhan kepada syariah. Pengungkapan informasi ini harus sesuai dengan prinsip-prinsip yang telah disusun dan dianut secara internasional sebagaimana telah disusun IFSB, sehingga bank syariah di Indonesia juga dapat diperbandingkan kinerja dan risikonya dengan bank syariah lain secara internasional.

Peningkatan transparansi dan disiplin pasar yang efektif juga harus didukung dengan tata-kelola perusahaan yang baik (good corporate governanceGCG). Sebagaimana telah disampaikan sebelumnya, pelaksanaan GCG pada bank syariah telah diatur Bank Indonesia dengan Peraturan Bank Indonesia Nomor 11/33/PBI/2009. Dalam peraturan ini disebutkan bahwa bank syariah (unit usaha syariah) harus melakukan transparansi kondisi keuangan dan nonkeuangannya. Dengan pelaksanaan tata-kelola perusahaan yang baik, diharapkan dapat mendorong prinsip-prinsip tata-kelola perusahaan yang baik dan memberikan insentif bagi manajemen bank, sehingga bank dengan tatakelola yang baik akan mendapat insentif dengan rendahnya tingkat keuntungan yang diharapkan (pendekatan harga) investor/deposan maupun kemudahan dalam mendapatkan dana dari para pelaku pasar. 
Meningkatkan Transparansi dan Disiplin Pasar Perbankan Syariah

\section{Kesimpulan dan Rekomendasi}

Transparansi dan disiplin pasar pada bank syariah hendaknya ditingkatkan. Hal ini mengingat deposan dan investor berkepentingan terhadap hasil investasinya yang secara teoritis relatif tidak pasti daripada bank konvensional yang menerapkan pembagian hasil yang lebih pasti dengan menggunakan tingkat bunga. Upaya ini harus didorong oleh Bank Indonesia dan pemerintah, diantaranya dengan pengungkapan informasi kondisi keuangan dan kesehatan bank secara berkala.

Kemampuan pasar, termasuk investor dan deposan pada bank syariah perlu ditingkatkan agar mampu melakukan pendisiplinan pasar secara efektif. Untuk itu, upaya edukasi pasar dan sosialisasi bank syariah perlu terus ditingkatkan mengingat kehadiran bank syariah yang relatif masih baru dibandingkan dengan bank konvensional.

Manajemen bank hendaknya meningkatkan tata-kelola bank dengan lebih baik, sehingga bank syariah yang baik mendapat insentif dari pasar, baik dengan rendahnya tingkat keuntungan yang diminta maupun kemudahan mendapatkan dana. Hal ini perlu didukung dan didorong oleh otoritas moneter (Bank Indonesia) melalui regulasi dan pemberian insentif kepada bank dengan tata-kelola yang baik.

Dari sisi pengembangan teoritis, penelitian tranparansi dan disiplin pasar perbankan di Indonesia masih memerlukan kajian dan penelitian lebih lanjut. Hal ini karena masih tampak berbagai variasi hasil penelitian yang telah ada dan terbatasnya kajian teoritis dan empiris mengenai bahasan ini. Kajian dan penelitian ini semakin relevan karena karakteristik khusus bank syariah sebagaimana telah dibahas di atas. Pengembangan teoritis dan praktis transparansi dan disiplin pasar bank syariah masih sangat terbuka dan membutuhkan kajian yang lebih mendalam sebagai tantangan akademis di kemudian hari. 


\section{DAFTAR PUSTAKA}

Ariffin, Noraini Mohd; Archer, Simon; Karim, Rifaat Ahmed Abdel. 2005. Transparency and Market Discipline in Islamic Banks. islamiccenter.kau.edu.sa

Basel Committee on Banking Supervision. 2001. "Working Paper on Pillar 3Market Discipline”. Bank for International Settlements

Hamalainen, Paul; Hall, Maximilian; Howcroft, Barry . 2003. "Market Discipline : a Theoritical Framework For Regulatory Policy Development" dalam Kaufman, George G., Market Discipline in Banking : Theory and Evidence. Elsevier.

Hamalainen, Paul; Hall, Maximilian; Howcroft, Barry . 2005. “A framework for Market Discipline in Bank Regulatory Design". Journal of Business, Finance \& Accounting. Vol 32 (1) \& (2), January/ March 2005, pp.183-209

Hasan; Tandelilin, Eduardus. 2012. "Banking Market Discipline in Indonesia an Empirical Test on Conventional and Islamic Banks". Journal of Indonesian Economy \& Business. Vol 27, Number 2, May 2012.

Hosono, Kaoru, Hiroko Iwaki, Kotaro Tsuru. 2005. "Banking Crises, Deposit Insurance, and Market Discipline: Lessons from the Asian Crises". RIETI Discussion Paper Series 05-E-029, October 2005

Jatna, Mardianto. 2007. Pengujian Efektivitas Market Disipline (Disiplin pasar) Pada Bank Umum di Indonesia dengan Balanced Panel Data Estimation. Tesis Magister Manajemen Universitas Gadjah Mada.

Lane, Timothy D. 1993. "Market Discipline". Staff Papers - International Monetary Fund, Vol. 40, No. 1 (Mar., 1993), pp. 53-88

Laeven, Luc. 2002. "Bank Risk and Deposit Insurance". The World Bank Economic Review, Vol. 16, No. 1, pp. 109-137

Levy-Yeyati, Eduardo, Maria Soledad Martinez Peria, Sergio L. Schmukler. 2004. "Market Dsicipline under Systemic Risk: Evidence from Bank Runs in Emerging Economies". Working paper 
Meningkatkan Transparansi dan Disiplin Pasar Perbankan Syariah -

Peria, Maria Soledad Martinez, Sergio L. Schmukler. 2001. "Do Depositors Punish Banks for Bad Behavior? Market Discipline, Deposit Insurance, and Banking Crises". The Journal of Finance, Vol. 56, No. 3, pp. 1029-1051

Saunders, Anthony dan Cornett, Marcia Millon. 2008. Financial Institution Management: A Risk Management Approach, International Edition. New York. Mc Graw Hill.

Stephanou, Constantinos. 2010. Rethinking Market Discipline in Banking Lessons from the Financial Crisis. The World Bank Policy Research Working Paper 5227

Taswan. 2011. Kepemilikan Bank, Kepatuhan Regulasi dan Disiplin Pasar : Kontrol Risiko Perbankan dan Moral Hazard Terkait Posisi Charter Value Pada Periode Penjaminan Simpanan Implisit dan Eksplisit. Ringkasan Disertasi Ujian Terbuka dan Promosi Doktor Fakultas Ekonomika dan Bisnis Universitas Gadjah Mada. Yogyakarta

Valensi, Mega. 2005. Who Disciplines Indonesian Banks? a Study of Market Discipline In Indonesia 1980-1999. Thesis for the Doctor of Philosophy of Department of Accounting and Finance Faculty of Business and Economics Monash University. Australia.

www.bi.go.id

www.ifsb.org 